\title{
STREET STORIES
}

The World of Police Detectives 



\section{STREET STORIES}

The World of

Police Detectives

ROBERT JACKALL

$\begin{array}{lllllllllllllllllllll}\text { H A } & \mathbf{R} & \text { V } & \text { A } & \mathbf{R} & \mathbf{D} & \text { U N N } & \text { I } & \text { V } & \text { E } & \text { R } & \text { S } & \text { I } & \text { T } & \text { Y } & \text { P } & \text { R } & \text { E } & \text { S } & S\end{array}$ Cambridge, Massachusetts, and London, England 
Copyright (C) 2005 by Robert Jackall

ALL RIGHTS RESERVED

Printed in the United States of America

Library of Congress Cataloging-in-Publication Data

Jackall, Robert.

Street stories : the world of police detectives / Robert Jackall.

$$
\text { p. cm. }
$$

ISBN 0-674-0I709-9 (cloth : alk. paper)

I. Criminal investigation-New York (State)-New York-Case studies.

2. Detectives-New York (State)-New York. I. Title.

HV8073.J23-2005

363.25'09747I-dc22

2004060793 
For my students at Williams College With great appreciation and affection 
